\title{
Effect of Follicular Fluid Oxidative Stress on Subsequent Oocyte Quality and Embryo Development
}

\author{
Folliküler Sıvı Oksidatif Stresin Oosit Kalitesi ve \\ Embriyo Gelişimi Üzerine Etkisi
}

\author{
Özgür BiGE, ${ }^{a}$ \\ Bülent GÜLEKLİ, \\ Ahmet DEMiR, ${ }^{a}$ \\ Funda GÖDE, ${ }^{a}$ \\ Semra KOÇTÜRK, ${ }^{b}$ \\ Fulya AYDINER, ${ }^{a}$ \\ Ali Burak ÖZKAYA, \\ Hatice GIRAYc \\ Departments of \\ aGynecology and Obstetrics, IVF Unit, \\ 'Biochemistry, \\ 'Public Health, \\ Dokuz Eylül University Faculty of Medicine, \\ İzmir
}

Geliş Tarihi/Received: 30.06 .2014

Kabul Tarihi/Accepted: 18.11.2015

Yazışma Adresi/Correspondence:

Özgür BiGE

Özel Star Medica Hospital,

Clinic of Gynecology and Obstetrics,

Tekirdağ,

TÜRKIYE/TURKEY

ozgurbigef@yahoo.com

\begin{abstract}
Objective: The role of oxidative metabolism on in vitro fertilization (IVF) has not been studied in detail. Our aim was to investigate the impact of oxidative stress markers on subsequent oocyte and embryo quality. Material and Methods: A total of 214 oocytes and their corresponding follicular fluid (FF) samples from 67 women undergoing intracytoplasmic sperm injection (ICSI) were assessed. The relationship between FF levels of oxidative stress markers [malondialdehyde (MDA), nitric oxide (NO) and protein carbonyl] levels and subsequent oocyte quality, fertilization and embryo morphologies were evaluated. Results: The mean MDA levels were significantly higher in FFs of fertilized oocytes. The mean NO levels were significantly lower in FFs of top-quality embryos whereas mean protein carbonyl levels were significantly higher in FFs of top quality embryos. Conclusion: FF oxidative stress seems to play an important role in fertilization and embryo morphology. Different oxidative stres pathways might have different effects on oocyte development, and also particular oxidative stress in FF might be needed for oocyte maturation.
\end{abstract}

Key Words: Embryonic structures; follicular fluid; oocytes; oxidative stress

ÖZET Amaç: Oksidatif metabolizmanın in vitro fertilizasyon (IVF) üzerindeki rolü çok iyi araştırılmamıştır. Amacımız oksidatif stres belirteçlerinin müteakip oosit ve embriyo kalitesine etkisini incelemektir. Gereç ve Yöntemler: ICSI uygulanan 67 hastadan elde edilen toplam 214 folliküler sıvı değerlendirildi. Folliküler sıvı oksidatif stres belirteç düzeyleri ile [Malondialdehit (MDA), nitrik oksit (NO) ve protein karbonil] takip eden oosit kalitesi, fertilizasyon ve embriyo morfolojileri arasındaki ilişki araştırıldı. Bulgular: Ortalama MDA seviyeleri fertilize olan oositlerin folliküler sıvılarında anlamlı olarak yüksekti. Ortalama NO seviyeleri yüksek kaliteli embriyo gelişen oositlerin folliküler sıvılarında anlamlı olarak düşükken ortalama protein karbonil düzeyleri anlamlı olarak yüksekti. Sonuç: Folliküler sıvı oksidatif stres, fertilizasyonda ve embriyo morfolojisinde önemli bir rol oynar gibi görünmektedir. Farklı oksidatif stres yolaklarının oosit gelişimi üzerinde farklı etkileri olabilir. Oosit matürasyonu için folliküler sıvıdaki belirli bir düzeyde oksidatif strese ihtiyaç olabilir.

Anahtar Kelimeler: Embriyonik yapılar; folliküler sıvı; oosit; oksidatif stres

Turkiye Klinikleri J Gynecol Obst 2016;26(1):1-6

TA

$\mathrm{n}$ vitro fertilization, an important assisted reproduction technique (ART), is widely used in infertility clinics all over the world. The L sucess of this technique is strongly associated with oocyte and embryo quality. Thus biochemical characteristics of follicular fluid surrounding oocytes play an important role in oocyte maturation and subsequent embryo quality. ${ }^{1}$ 
Reactive oxygen species (ROS) and reactive nitrogen species (RNS) are produced beside main end products during normal metabolic processes in all aerobic organisms. The antioxidant defense systems in the body try to eliminate the possible deleterious effects of these species in normal physiological conditions. If the generation of ROS/RNS exceed the capacity of antioxidant defense systems, this imbalance is defined as oxidative/nitrosative stress which may cause damage to the living organism and it's constituents such as DNA, lipids, proteins and carbohydrates. ${ }^{2,3}$ Oocyte and surrounding FF contents, steroid hormones, growth factors, cytokines, granulose cells, and leukocytes contribute to the production of ROS and RNS during folliculogenesis. ${ }^{4}$ Although the impact of ROS seems to be hazardous for the oocyte development, the exact relationship between oxidative stres markers and subsequent embryo quality is not fully clarified. Thus, some favorable and unfavorable reflections of ROS and antioxidant systems have been shown in female infertility so far. ${ }^{5,6}$

The objective of the current study was to investigate the impact of oxidative stress on oocyte quality, fertilization and embryo morphologies. To determine the oxidative stres status we measured the malondialdehyde (MDA), protein carbonyl and nitrite/nitrate levels in FFs of preovulatory follicles at the time of oocyte pick up (OPU) procedure of women undergoing ICSI.

\section{MATERIAL AND METHODS}

\section{PARTICIPANTS}

This prospective study was carried out in the In Vitro Fertilization (IVF) Unite, Department of Obstetrics and Gynecology, Dokuz Eylul University Hospital, between January 2008 and August 2008. Sixty seven infertile couples, who underwent ICSI cycle due to unexplained infertility and male factor were enrolled into the study. All the women were non-smokers. All of the subjects were free of systemic diseases such as thyroid function disorders, diabetes mellitus and hyperprolactinemia, and were on their first IVF treatment cycle. Women with a history of ovarian surgery, polycystic ovary syndrome (PCOS) or PCO and ovulatory disorders were not included. Institutional ethics committee approved the study protocol, and written informed consent was obtained from each couple.

\section{OVARIAN STIMULATION, FOLLICULAR FLUID SAMPLING, AND OOCYTE COLLECTION}

All women underwent a long protocol with a gonadotropin-releasing hormone ( $\mathrm{GnRH}$. Ovarian stimulation with recombinant follicle-stimulating hormone (FSH) was begun after pituitary supression was confirmed. Human chorionic gonadotropin (hCG) was administered when there were at least two follicles of $\geq 18 \mathrm{~mm}$ diameter. Oocyte pick up was performed under transvaginal ultrasound guidance $36 \mathrm{~h}$ after the hCG injection. FF was aspirated separately from each follicle with a cannula of 15 to $20 \mathrm{~mm}$ in diameter and collected in individual tubes. After each aspiration procedure, to prevent the contamination of subsequent FF, the aspiration conduits were cleaned and a new collecting tube was used. FF that contained more than one oocyte or no oocyte or contaminated with culture medium or significant amount of blood cells were excluded from the study. One to five follicles were aspirated separately from each patient. After oocyte isolation under stereo-microscope examination, the FF from each follicle was collected separately into the sterile individual tube.

\section{ASSESSMENT OF OOCYTE MORPHOLOGY AND OOCYTE MATURATION}

Oocytes isolated from samples of FF were evaluated separately from the other oocytes. The cumulus oophorus and corona radiata were removed from oocytes by mechanical and chemical (hyaluronidase) methods. Nuclear maturation of oocytes was determined by the identification of first polar body. Morphological evaluation of each oocyte was also performed and was based on morphology of cytoplasm, extracytoplasmic structures such as zona pellucida, the first polar body, and perivitelline space. ${ }^{7}$ Oocyte was considered as normal when it had a round clear zona pellucida, small perivitelline space, containing single unfragmanted first polar body, and a pale moderately granular cytoplasm that did not contain inclusions. Other forms of oocytes were considered as abnormal. 


\section{INTRACYTOPLASMIC SPERM INJECTION (ICSI) AND SPERM PREPARATION}

All retrieved oocytes were incubated for 2 to $4 \mathrm{~h}$ until ICSI was performed. All oocytes taken in the study group underwent ICSI procedure to standardize the study. Semen samples from the male partners were obtained by masturbation. When no sperm was present in the sample, testicular sperm extraction (TESE) was performed. Spermatozoa were prepared first by density gradient centrifugation and then swim up. The ICSI procedure was carried out only on mature (Metaphase-II, MII) oocytes as defined by van Steirteghem et al. ${ }^{8}$

\section{FERTILIZATION, CLEAVAGE AND EMBRYO EVALUATION}

Fertilization was confirmed $18 \mathrm{~h}$ after the ICSI procedures by visualization of two distinct pronuclei and two polar bodies under the inverted microscope (Olympus IX70, Olympus, Melville, NY, USA). Embryo quality was assessed on the third day of insemination and graded on the basis of morphologic appearance and fragmentation according to modified criteria of Veeck. The embryos were scored as follows: grade I, symmetric blastomers and no fragmentation, grade II, different blastomers in size and shape with-, $<25 \%$ fragmentation; and grade III: different blastomers in size and shape with-, > $25 \%$ fragmentation..$^{9}$ To simplify the analysis, the graded embryos were divided into two groups: Group A (top quality, grade I) and group B embryos (subquality, grade II, grade III). Biochemical pregnancy was diagnosed when the $\mathrm{B}$ hCG level >25 mIU/ml 14 days after the embryo transfer. Cinical pregnancy was defined by the visualization of a heart beat belong to one or more embryos by transvaginal ultrasound three weeks after the embryo transfer.

\section{MEASUREMENT OF OXIDATIVE STRESS MARKERS IN FOLLICULAR FLUID}

Lipid peroxides, derived from polyunsaturated fatty acids, are unstable and decompose to form reactive carbonyl compounds. The most abundant one is MDA which is widely used as an indicator of lipid peroxidation. ${ }^{10} \mathrm{MDA}$ in the FFs was analyzed by a commercial MDA kit (MDA-586, Biotech, OxisRe- search, Portland, USA). Nitric oxide was measured in the FF by detecting the total levels of stable oxidation products of NO metabolism (Nitrite/Nitrate, NO2/NO3) by Griess reaction with the commercial kit (Nitrate/Nitrite Colorimetric Assay Kit 780001, Cayman Chemical, Michigan, USA). To measure oxidized protein (protein carbonyl) in the FF protein carbonyl assay kit (Protein Carbonyl Colorimetric Assay Kit, Cayman Chemical, Michigan, USA) was used.

\section{STATISTICAL ANALYSIS}

Statistical analyses were performed by SPSS (Statistical Package for Social Sciences, version 11,0,SPSS Inc-, Chicago, IL). One-way analysis of variance (one-way ANOVA) with Bonferroni's post hoc correction, Kruskal-Wallis, Mann-Whitney U-test with Bonferroni correction, $\mathrm{t}$ test and chi-squared test were used as appropriate. All data were presented as mean \pm standard error, $\mathrm{P}<0.05$ was considered statistically significant.

\section{RESULTS}

In the present study, $214 \mathrm{FF}$ samples from 67 women were analyzed. The average number of the retrieved oocytes for the first 1-5 punctures was $3.3 \pm 1.2$ (range, 1-5). Of 214 oocytes, 192 were MII. However 13 MII oocytes, obtained from three male factor infertility patients, were not inseminated because no sperm was found from TESE on the day of oocyte collection. 179 ICSI procedures were performed to the remaining oocytes. Afterwards 141 of these 179 mature oocytes were fertilized and 135 embryos were ob-

TABLE 1: Clinical characteristics of patients grouped by outcome of the procedure.

\begin{tabular}{|lccc|}
\hline & $\begin{array}{c}\text { Fertilized } \\
(\mathbf{n}=141)\end{array}$ & $\begin{array}{c}\text { Unfertilized } \\
(\mathbf{n}=38)\end{array}$ & $\mathbf{p}$ value \\
& $32.59 \pm 0.44$ & $31.24 \pm 0.76$ & 0.15 \\
Age (years) & $3049.5 \pm 214.6$ & $3196.2 \pm 233.0$ & 0.75 \\
Gonadotropin dose (IU) & $11.45 \pm 0.57$ & $11.04 \pm 0.78$ & 0.92 \\
Induction length (d) & $16.32 \pm 1.12$ & $15.71 \pm 1.43$ & 0.32 \\
Number of follicles $>14 \mathrm{~mm}$ & $13.52 \pm 0.78$ & $12.62 \pm 1.04$ & 0.90 \\
Number of oocytes & $8.62 \pm 0.53$ & $7.74 \pm 0.85$ & 0.17 \\
\hline Number of embryos & & & \\
\hline
\end{tabular}


tained. The characteristics and treatment of ICSI according to the result of fertilization were summarized in (Table 1).

We initially compared the levels of three oxidative stres markers in FF of abnormal and normal oocytes according to morphological evaluation. Mean MDA levels were $9.02 \pm 1.99$ and $5.43 \pm 0.39$ $\mathrm{mml} / \mathrm{L}$ in the normal $(\mathrm{n}=32)$ and abnormal oocyte $(\mathrm{n}=182)$ group respectively. The difference was statistically significant $(\mathrm{p}<0.05)$. We did not detect significant difference between the levels of $\mathrm{NO}$, protein carbonyl levels in FF according to oocyte morphology.

According to fertilization, the mean FF MDA levels of the fertilized group ( $\mathrm{n}=141)$ were significantly higher than that of the unfertilized group $(\mathrm{n}=38)(\mathrm{p}<0.05)$ (Table 2). There was no association between levels of $\mathrm{NO}$ and protein carbonyl in FF and fertilization.

Forty two embryos were transferred on second day of insemination. Ninty three embryos were evaluated on third day of insemination. Mean NO levels were $45.62 \pm 1.40$ in subquality embryo group $(\mathrm{n}=50)$ and $40.85 \pm 1.79 \mathrm{nmol}$ in topquality embryo group ( $n=43)$. The difference was statistically significant $(\mathrm{p}<0.05)$. Moreover mean protein carbonyl levels were significantly higher in FFs of top quality embryos $(p<0.05)$ (Table 3$)$. We did not detect significant difference between MDA levels according to embryo quality. MDA levels were significantly higher in conceived patients compared to not- conceived patients (Table 4).

\section{DISCUSSION}

Trials conducted within the past decades have shown that oxidative stress increases embryo fragmentation by inducing apoptosis, decreases hatch-
TABLE 2: Comparison of the levels of oxidative stress markers according to fertilization.

\begin{tabular}{|lccc|}
\hline & $\begin{array}{c}\text { Fertilized } \\
(\mathbf{n}=141)\end{array}$ & $\begin{array}{c}\text { Unfertilized } \\
(\mathbf{n}=38)\end{array}$ & p value \\
& $5.24 \pm 0.35$ & $3.69 \pm 0.34$ & 0.027 \\
MDA ( $\mu$ mol/L) & $43.93 \pm 0.88$ & $42.34 \pm 2.12$ & 0.491 \\
Nitrite/Nitrate (NO) & & & \\
(nmol NO/mg protein) & & & \\
Protein carbonyl (nmol/ml) & $14.47 \pm 0.62$ & $15.99 \pm 1.26$ & 0.285 \\
\hline
\end{tabular}

TABLE 3: Comparisons of the levels of the oxidative stress markers according to embryo quality on third day after ICSI procedure

\begin{tabular}{|cccc|}
\hline & $\begin{array}{c}\text { Group A } \\
(\mathrm{n}=43)\end{array}$ & $\begin{array}{c}\text { Group B } \\
(\mathrm{n}=50)\end{array}$ & p value \\
& $6.17 \pm 0.80$ & $5.43 \pm 0.60$ & 0.469 \\
MDA $(\mu \mathrm{mol} / \mathrm{L})$ & $40.85 \pm 1.79$ & $45.62 \pm 1.40$ & 0.039 \\
Nitrite/Nitrate $(\mathrm{NO})$ & & & \\
$(\mathrm{nmol} \mathrm{NO} / \mathrm{mg} \mathrm{protein})$ & & & \\
Protein carbonyl $(\mathrm{nmol} / \mathrm{ml})$ & $17.94 \pm 2.31$ & $13.58 \pm 0.63$ & 0.032 \\
\hline
\end{tabular}

Group A: Top quality embryos; Group B: Subquality embryos.

ing rate of the embryo, have deleterious effects on the embryo, decreases implantation rate, and also causes luteal phase defect. ${ }^{11-14}$ However, some studies found a positive correlation between FF ROS levels and oocyte maturation parameters. ${ }^{11,12}$ Interestingly we also found a positive correlation between mean MDA levels in FF and normal oocyte morphology. In this manner, we think that optimal levels of oxidative stress might be necessary for oocyte development and subsequent embryo quality.

In our study, MDA levels were significantly higher in FFs of fertilized oocytes than unfertilized oocytes in contrast to some studies. ${ }^{5,15,16}$ There may be two possible explanations of this relationship. First, oxidative stress which leads to lipid peroxidation may be necessary for fertilization. Second,

\begin{tabular}{|c|c|c|c|}
\hline & Conceived $n=31$ & Not-conceived $n=31$ & \\
\hline Embryo transferred patients $n=62$ & Mean \pm SE & Mean \pm SE & $p$ value \\
\hline MDA $(\mu \mathrm{mol} / \mathrm{L})$ & $7.18 \pm 0.79$ & $4.70 \pm 0.60$ & 0.005 \\
\hline Nitrite/Nitrate (NO) (nmol NO/mg protein) & $43.39 \pm 1.23$ & $44.04 \pm 0.80$ & 0.658 \\
\hline Protein carbonyl (nmol/ml) & $15.41 \pm 0.77$ & $14.04 \pm 0.65$ & 0.175 \\
\hline
\end{tabular}


the increased fertilization capacity of oocytes may require high energy levels, and therefore oocytes may try to increase mitochondrial number and activity to supply increased energy demand. As a result, ROS and subsequent lipid peroxidation may be secondary to production of increased aerobic energy metabolism. However, there are also some contradictory reports that found no correlation between lipid peroxidation and fertilization. ${ }^{11,17}$ In contrast to these studies, Biondin et al. found a positive relation between oocyte maturation and oxidative stress during in vitro maturation similar with our findings. ${ }^{12}$

The factors that effect the embryo development are very important for the success of IVF. A substantial body of evidence has revealed that oxidative stress has detrimental effects on embryo development by different mechanisms such as mitochondrial alterations, diminishing the dividing of blastomeres, decreasing ATP levels, and inducing apoptosis. ${ }^{18,19}$ Therefore, the effect of oxidative stress on embryo development is a very complex process. In the present study, there was a negative correlation between NO concentrations and embryo quality. Reactive nitrogen species are formed in the organism as a result of aerobic metabolism beside ROS. ${ }^{3}$ Recent studies have shown that the FFs of IVF patients have considerable amount of NO, which is synthesized by the granulosa cells..$^{18,19}$ Therefore, it is possible that NO is associated with follicular physiology. Although Manau et al. could not find any correlation between NO and embryo quality, most of the studies have concluded that the NO concentrations in FFs were negatively correlated with embryo quality, similar with our study results. ${ }^{20-23}$

The oocyte protein synthesis is kept under control by maternal mRNA along $48 \mathrm{~h}$ following fertilization till the third division of the embryo. The subsequent process is under control of embryonic genome. ${ }^{23}$ Protein oxidation is one of the main mechanisms of interaction of the oxidative stres with proteins in the organism. Protein carbonyl is produced as a result of protein oxidation. There- fore, protein carbonyl is used to measure oxidized protein levels in the organism. ${ }^{24,26}$ In our study, we found that protein carbonyl levels in FFs were significantly higher in FF of top quality embryos. These results seem to support our results mentioned above concerning the relationship between oxidative stress markers and fertilization.

There are some limitations of our study. Our numerical data did not represent the whole oocyte and FFs of each individual patient. In other words we did not analyze and follow each FF and every oocyte separately, therefore, it was not possible to detect the individual pregnancy rate from each oocyte. We also were not able to define the associated cut off values regarding sensitivity, specificity, PPV, and NPV (Table 4). However, the mean number of oocytes in the study group was $3.3 \pm 1.2$ and the FF amounts did not represent each individual woman. In the present study the mean FF MDA levels in the successfully conceived were significantly higher than non-conceived women (Table 4). Attaran et al. showed that ROS levels were higher in follicles of successfully conceived women compared with unsuccessful ones. They have suggested that FF ROS levels may be used to predict the IVF success especially when they were in low concentrations. ${ }^{18}$ Wiener-Megnazi et al suggested a certain threshold of oxidative stress may be required for successful IVF pregnancies. ${ }^{26}$

In conclusion, $\mathrm{FF}$ oxidative stress seems to play an important role in oocyte quality, fertilization and embryo morphology. Increased oxidative stress does not always mean a detrimental effect on IVF outcome. Although a negative correlation between FF NO levels and embryo quality shows a potential deleterious effect of oxidative stress, a positive correlation between FF protein carbonyl levels and embryo quality points out to a contrast. Different oxidative stres pathways might have different effects on oocyte development, and also particular oxidative stress in FF might be needed for oocyte maturation. To clarify these findings, further studies are needed. 


\section{REFERENCES}

1. Revelli A, Delle Piane L, Casano S, Molinari E, Massobrio M, Rinaudo P. Follicular fluid content and oocyte quality: from single biochemical markers to metabolomics. Reprod Biol Endocrinol 2009;7:40.

2. Halliwell B, Gutteridge JMC. The chemistry of free radicals and related 'reactive radicals'. Free Radicals in Biology and Medicine. $3^{\text {rd }} \mathrm{ed}$. New York: Oxford University Press; 1999a; $p$. 246-350.

3. Halliwell B, Gutteridge JMC. The chemistry of free radicals and related 'reactive radicals'. Free radicals in biology and medicine. $3^{\text {rd }} \mathrm{ed}$. New York: Oxford University Press 1999b. p. 36-104.

4. Agarwal A, Gupta S, Sekhon L, Shah R. Redox considerations in female reproductive function and assisted reproduction: from molecular mechanisms to health implications. Antioxid Redox Signal 2008;10(8):1375-403.

5. Oyawoye O, Abdel Gadir A, Garner A, Constantinovici N, Perrett C, Hardiman P. Antioxidants and reactive oxygen species in follicular fluid of women undergoing IVF: relationship to outcome. Hum Reprod 2003;18(11):2270-4.

6. Guérin P, El Mouatassim S, Ménézo Y. Oxidative stress and protection against reactive oxygen species in the pre-implantation embryo and its surroundings. Hum Reprod Update 2001;7(2):175-89.

7. Ubaldi F, Rienzi L. Morphological selection of gametes. Placenta 2008;29(Suppl B):115-20.

8. Van Steirteghem A, Liu J, Nagy Z, Joris H, Tournaye $\mathrm{H}$, Liebaers I, et al. Use of assisted fertilization. Hum Reprod 1993;8(11):1784-5.

9. Veeck LL. Preembryo grading. Atlas of the Human Oocyte and Early Conceptus. Vol. 2. Baltimore: Wiliams and Wilkins; 1991. p.12149. 2006;21(9):2403-7.
10. Esterbauer H, Schaur RJ, Zollner H. Chemistry and biochemistry of 4-hydroxynonenal, malondialdehyde and related aldehydes. Free Rad Biol Med 1991;11(1):81-128.

11. Attaran M, Pasqualotto E, Falcone T, Goldberg JM, Miller KF, Agarwal A, et al. The effect of follicular fluid reactive oxygen species on the outcome of in vitro fertilization. Int J Fertil Womens Med 2000;45(5):314-20.

12. Biondin $P$, Coenen $K$, Sirard MA. The impact of reactive oxygen species on bovine sperm fertilizing ability and oocyte maturation. J Androl 1997;18(4):454-60.

13. Iborra A, Palacio JR, Martinez P. Oxidative stress and autoimmune response in the infertile woman. Chem Immunol Allergy 2005;88:150-62.

14. Agarwal A, Allamaneni SS. Role of free radicals in female reproductive diseases and assisted reproduction. Reprod Biomed Online 2004;9(3):338-47.

15. Paszkowski T, Traub Al, Robinson SY, McMaster D. Selenium dependent glutathione peroxidase activity in human follicular fluid. Clin Chim Acta 1995;236(2):173-80.

16. Das S, Chattopadhyay R, Ghosh S, Ghosh S, Goswami SK, Chakravarty BN, et al. Reactive oxygen species level in follicular fluid-embryo quality marker in IVF? Hum Reprod

17. Pasqualotto EB, Agarwal A, Sharma RK, Izzo VM, Pinotti JA, Joshi NJ, et al. Effect of oxidative stress in follicular fluid on the outcome of assisted reproductive procedures. Fertil Steril 2004;81(4):973-6.

18. Pierce GB, Parchment RE, Lewellyn AL. Hydrogen peroxide as a mediator of programmed cell death in the blastocyst. Differentiation 1991;46(3):181-6.
19. Yang HW, Hwang KJ, Kwon HC, Kim HS, Choi KW, Oh KS. Detection of reactive oxygen species (ROS) and apoptosis in human fragmented embryos. Hum Reprod 1998; 13(4):998-1002.

20. Barroso G, Barrionuevo M, Rao P, Graham L, Danforth D, Huey S, et al. Vascular endothelial growth factor, nitric oxide, and leptin follicular fluid levels correlate negatively with embryo quality in IVF patients. Fertil Steril 1999;72(4):1024-6.

21. Battaglia C, Regnani G, Marsella T, Facchinetti F, Volpe A, Venturoli S, et al. Adjuvant $\mathrm{L}$-arginine treatment in controlled ovarian hyperstimulation: a double-blind, randomized study. Hum Reprod 2002;17(3):659-65.

22. Manau D1, Balasch J, Jiménez W, Fábregues F, Civico S, Casamitjana R, et al. Follicular fluid concentrations of adrenomedullin, vascularendothelial growth factor and nitric oxide in IVF cycles: relationship to ovarianresponse. Hum Reprod 2000;15(6):1295-9.

23. Vignini A, Turi A, Giannubilo SR, Pescosolido $D$, Scognamiglio $P$, Zanconi $S$, et al. Follicular fluid nitric oxide (NO) concentrations in stimulated cycles: the relationship to embryo grading. Arch Gynecol Obstet 2008;277(3): 229-32.

24. Stadtman ER, Levine RL. Protein oxidation. Ann N Y Acad Sci 2000;899:191-208.

25. Du J, Gebicki JM. Proteins are major initial cell targets of hydroxyl free radicals. Int J Biochem Cell Biol 2004;36(11):2334-43.

26. Wiener-Megnazi Z, Vardi L, Lissak A, Shnizer $S$, Reznick AZ, Ishai D, et al. Oxidative stress indices in follicular fluid as measured by the thermochemiluminescence assay correlate with outcome parameters in vitro fertilization. Fertil Steril 2004;82(Suppl 3):1171-6. 